\title{
6 Appendix I: Survey of didactic poems
}

\section{Introductory note}

No claim to completeness whatsoever is attached to the following list of didactic poems. The texts listed and arranged by subject matter are those which I have come across in the process of cataloguing the Arabic manuscripts of the BSB Munich as well as in my random readings. Their arrangement follows the classification of Ahlwardt as proposed in his Verzeichniss.

The fields of knowledge in the Middle Ages were divided into Islamic sciences, philosophical and natural sciences and the literary arts. The Islamic sciences, of course, i.e. sciences related to the Koran, Hadith and law, had total pre-eminence in the institutions of learning (Makdisi 1981, 75). Grammar, encompassing the literary arts as well as poetry, was considered an indispensable tool for understanding the language of the Koran and Hadith, although as a subject in the curriculum, it was subordinate to them and to the law. Poetry was justified on the basis that it offered evidence of the lexical meanings of the Koran (Makdisi 1981, 76). A characteristic feature of Muslim education was the dichotomy between the religious and the foreign sciences, the former being called al-ulūm al-islämiyya or shar'iyya or al-mutasharri' $a$ (79). Corresponding to the preponderance of the religious over the foreign sciences, most of the didactic poems listed below deal with Koranic sciences, law and grammar, and only very few have been composed in explanation of the natural sciences.

\subsection{Recitation of the Koran}

\subsection{1 -Shāṭibī (Ḥirz al-amānī, Nāẓimat al-zahr, etc.)}

Abū Muhammad al-Qāsim b. Firroh b. Khalaf b. Aḥmad al-Ru'aynī al-Andalusī al-Shāṭibī (d. 590/1194; EI 9,365-66; GAL 1,520-22 S 1,725; Kaḥhāla 8,110-11) authored a poem entitled Hirz al-amānī wa-wajh al-tahānī (known as al-Shāțibiyya) which is a versification ${ }^{171}$ of al-Dānī al-Qurțubī's K. al-Taysīr fì l-qirā'āt $a l$-sab on the seven readings of the Koran.

Some manuscripts of the Hirz al-amāni in possession of the BSB Munich are: Cod.arab. 1060 (= VOHD XVIIB8 no. 3), 1755, 1802, 1882 (dated 1084/1673; cf. my

171 On memorizing this poem see supra, p. 96.

(c) BY-NC-ND $($ C) 2016 Florian Sobieroj, published by De Gruyter.

This work is licensed under the Creative Commons Attribution-NonCommercial-NoDerivs 3.0 License. 
description in VOHD XVIIB12] see fig. 25); 1894 (dated 1037/1628); a commentary on Hirz al-amānì is Cod.arab. 1587.

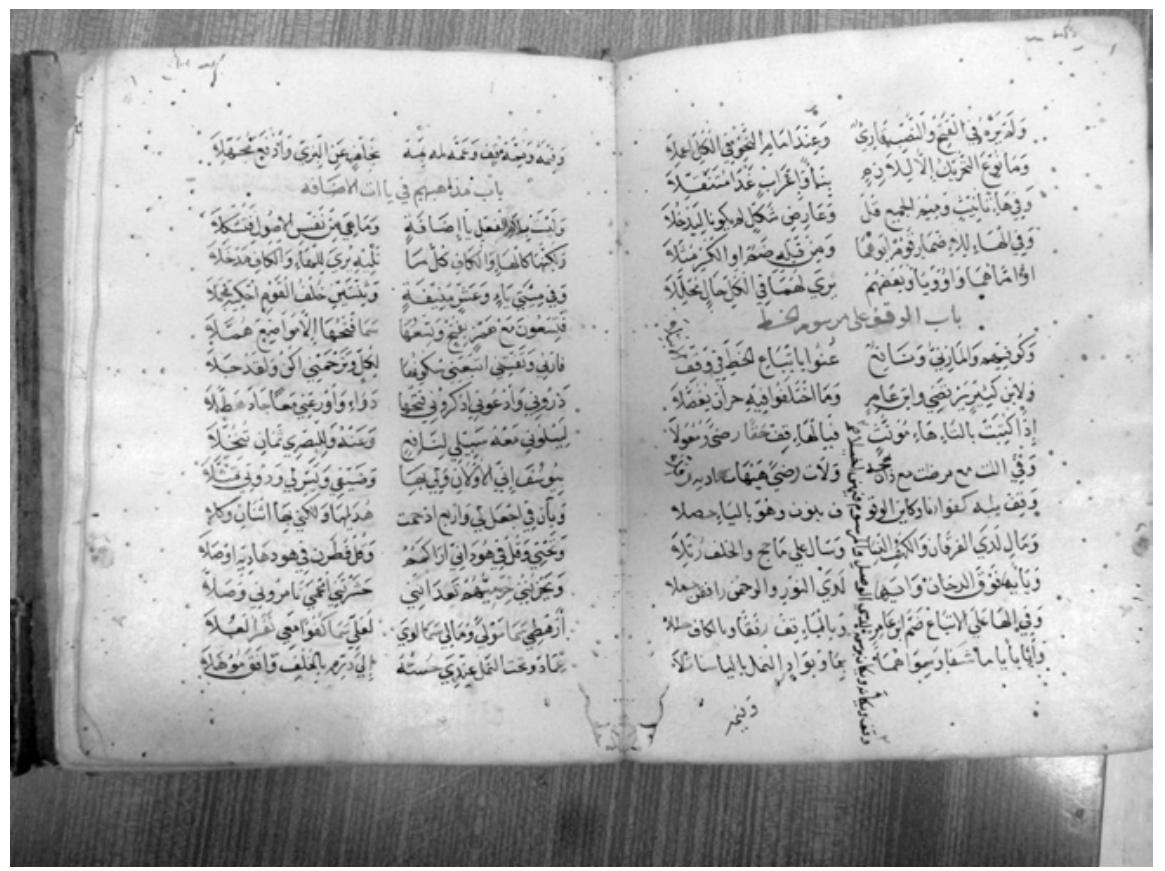

Fig. 25: Al-Shāțibī: Ḥirz al-amānī, poem in Ṭawīl verses on Koranic readings, 1084/1673; 15 lines per page in two columns; red chapter headings; fo. 15v, an omitted verse has been supplied between the columns (BSB Cod.arab. 1882, fo. 15v-16r).

Another didactic poem on Koran recitation, by the same author, is entitled Nāzimat al-zahr fì a'dād āyāt al-Qur'ān al-sharîf (GAL 1,522,V, S 1,727) is BSB Cod.arab. 1574; it has 297 verses "on determining the number of verses in the Koran" (Garrett no. 1195).

A didactic poem on the readings of three of the ten most important readers is Farā'id al-durar, with 369 verses in the Țawill metre, written by Ahmmad b. Sa 'ìd alYamanī (d. 839/1435-6). A manuscript of a commentary on Farā'id al-durar is BSB Cod.arab. 1585. The Qașìda of al-Yamanī has been considered to be an imitation of al-Shāțibī's Hirz al-amānī.

BSB Cod.arab. 1073 (VOHD XVIIB8 no. 16/2) contains two texts on Koran recitation. The first is the above-mentioned prose text al-Taysir fi l-qirä'ät al-sab' of al-Dānì al-Qurțubì (d. 444/1053) on the readings of the Koran according to the 
seven major readers and two of their students; the second is a didactic poem on the pauses (waqf) which are (considered necessary) to be observed while reciting the holy text. This poem, entitled Kitāb al-Shaykh Shams al-'ārifin, and found in the manuscript on pages 423-424 (according to the pagination of a recent hand), is in the Wāfir-metre, rhymes in -na, and seems to be a versification of the prose text K. al-Waqf wa-l-ibtidā' of Abū Ja 'far M. b. Țayfūr al-Sajāwandī al-Ghaznawī (d. 560/1164; two Mss. of the tract are Manchester [Mingana] no. 65; Ahlwardt no. $570,8)$. The poem is arranged according to the order of the Suras in the Koran which may be considered a mnemotechnical device. The Koranic words where, during recitation, a pause is to be observed, have been enumerated in Cod.arab. 1073 by means of small numbers written above the lines.

\subsubsection{Ibn al-Jazarī}

The full name of the author of the didactic poem known as al-Muqaddima alJazariyya runs Shams al-Dīn Abū l-Khayr Muhammad b. Muhammad b. Muhammad Ibn al-Jazarī al-Qurashī al-Dimashqī al-Shīrāzī (d. 833/1429; GAL 2,257-61 S 2,274; EI 3,753; Kaḥhāla 11,291-2; TDVİA 20,551-7; Bauer 2011, ch. 3). Ibn al-Jazarī was born in Damascus in 751/1350, but his shuhra relates back to Jazirat Ibn 'Umar - literally: the island, formed by the Tigris - the modern Cizre in the Sirnak province in southeast Anatolia. He travelled a number of times to Cairo where he studied under renowned teachers and obtained the license to issue fatwas. After the completion of his studies the scholar taught Koranic readings at the Great Mosque of Damascus, the -Jāmi` al-Umawī.

Ibn al-Jazarī's work on Koran recitation whose title is also given as alMuqaddima fi tajwīd al-Qur'ān, counts 107-109 verses (cf. Ms. Ahlw. no. 500). At the beginning of his commentary entitled al-Daqā'iq al-muhkama fi sharh alMuqaddima, Abū Yaḥyā Zakariyyā al-Anșārī (d. 926/1520; GAL 2,122-24) mentions that the poem, in the majority of manuscripts ('alā mā fi akthar al-nusakh), extends to 107 verses whereas, in a minority of copies, it comprises 108 verses (BSB Cod.arab. 1952, fo. 63v). According to another commentator, Ahmmad b. Muṣlih aldīn Ṭāshköprüzade (d. 968/1560; GAL 2,559-62), the Urjūza of Ibn al-Jazarī is the best work ever composed on the science of Koran recitation (BSB Cod.arab. 1952, fo. $2 \mathrm{v}$ ); the commentator extolls al-Jazarī as "the unique shaykh, the learned and worker, the excellent and perfect (al-shaykh al-wahìd al- 'âlim al-'āmil al-fädil al$k \bar{a} m i l)$, the head of hadīth scholars and the elect of tajwìd specialists”. Al-Anșārī, in turn, praises the didactic poem for its beauty and succinctness (husn al- 
ikhtișār); he also lauds it for the fact that, despite its short length, it includes numerous things which cannot be found in many of the larger books on the subject. However he also maintains that the Muqaddima is in need of an explanation of its meanings (kānat muḥtājatan ilā bayān al-murād), for which reason he composed his commentary (BSB Cod.arab. 1952, fo. 63v). ${ }^{172}$

\subsubsection{Commentaries}

Abū Bakr Aḥmad b. al-Jazarī, the author's son, wrote a commentary entitled $K$. al-Hawāshì al-mufahhima fì sharh al-Muqaddima (one manuscript is BSB Cod.arab. 1607 = VOHD XVIIB9 no. 237/2); Ṭāshköprüzade (supra) wrote his commentary (Sharh al-M. al-Jazariyya) to complement that of the author's son, but apologizes for the shortcomings which the reader may detect in his own sharh. These, he writes, were due to the fact that he composed the commentary while travelling, literally, "on the wings of a journey”, while he was also much preoccupied with other things - which affected his memory (katabtuhū 'alā janāh alsafar ... wa-wuqū'i fì hawādith ākhar bi-kull al-dhihn 'an tidhkārihā; BSB Cod.arab. 1952, fo. 49r). Zakariyyā' al-Anșārī wrote al-Daqā’iq al-muhkama fì sharh alMuqaddima of which manuscripts are listed in GAL 2,124,53, S 2,276; additional Mss., in the BSB Munich are Cod.arab. 1485, 1607, part 4, 1952, part 4); further commentaries include the following: Muhammad b. Muhammad al-Hijāzī (eleventh/seventeenth c.), K. al-Hidāya al-nabawiyya fi sharh al-Jazariyya (BSB Cod.arab. 1502 = XVIIB9 no. 168); 'Alā' al-Dīn al-Ṭarābulusī (d. 1032/1623), Kitāb al-tajwīd (one manuscript is BSB Cod.arab. 1607 = XVIIB9 no. 237/5); anonymous commentaries on al-Muqaddima (ninth/fifteenth c.) are BSB Cod.arab. 1127 (VOHD XVIIB8 no. 70) and Cod.arab. 1539 (XVIIB9 no. 205). A super-commentary on the Muqaddima is BSB Cod.arab. 1491 (= VOHD XVIIB9 no. 157) authored by Muḥammad b. 'Abd al-Raḥmān al-Nābulī (fl. 1277/1860) and entitled al-Durar alsaniyya 'alā Sharh al-Shaykh Khālid li-l-Jazariyya. Al-Nābulī's work is based on the commentary of Khālid al-Azharī al-Jirjāwī (d. 905/1499) on the Muqaddima

172 Manuscripts of the Muqaddima: GAL 2,259,8, S 2,275,8; SBB, Lbg. 95, fo. 472v-75v (= Ahlw. no. 508), Lbg. 151, fo. 156-59 (= Ahlw. no. 501), Lbg. 975, fo. 36v-40r (= Ahlw. no. 507), Lbg. 993, fo. 4v-6v (= Ahlw. no. 506), Pet. 703, fo. 1-6r (= Ahlw. no. 502), Mq. 77, fo. 1-20 (= Ahlw. no. 503), Spr. 1956, fo. 1-4v (= Ahlw. no. 505), We. 1309, fo. 82v-87v (= Ahlw. no. 500), We. 1781, fo. 27-31(= Ahlw. no. 510), Hs. or. 4482 (= VOHD XVIIB3 no. 17); Hs. or. 4775 (= VOHD XVIIB3 no. 18); Hs. or. 5055 (= VOHD XVIIB5 no. 7, 13); Hs. or. 5111 (= VOHD XVIIB5 no. 8); Hs. or. 5059 (= VOHD XVIIB5 no. 9), BSB München, Cod.arab. 1110 (=VOHD XVIIB8 no. 53, part 25-26), Cod.arab. 1607/1 ( = VOHD XVIIB9 no. 273, part 1). The text has been printed and translated into Persian (cf. GAL S $2,276,8)$. 
and it is a rare, if not unique, manuscript witness of this text. Finally, a certain Muhạmmad b. Kamāl al-Dīn al-Maydānī authored a commentary on the Muqaddima entitled al-Fawā'id al-muharrara - not mentioned in GAL - of which one manuscript is BSB Cod.arab. 1764, part 2 (cf. VOHD XVIIB12).

Ibn al-Jazarī also composed, in 823/1420, another poem on Koran recitation with 240 verses, bearing the title al-Durra al-mudī'a fi qirā'at al-a'imma althalātha al-mardiyya (an alternative title is al-Manzūma al-Jazariyya; cf. GAL S 2,275,4). A manuscript of a commentary by the contemporaneous author Muhibb al-Dīn al-Nuwayrī (d. 857/1453; GAL S 2,21 275,4,f) entitled Sharh al-Durra almuḍī'a is BSB Cod.arab. 1406.

\subsection{Orthography of the Koran: -Shāțibī ('Aqīlat atrāb al- qașā'id)}

Al-Qāsim b. Firroh al-Shātịīís didactic poem on the orthography of the Koran, entitled 'Aqūlat atrāb al-qașā'id fì asnā l-maqāṣid, is a versification with rhyme consonant rā' of al-Muqni' fì ma'rifat rasm (khațt) mașāhif al-amșār by Abū 'Amr 'Uthmān b. Sa'īd b. 'Uthmān al-Dānī al-Qurțubī (d. 444/1053 or 441; GAL 1,51617). The Muqni ' deals with the collection of the Koran and its orthography (manuscripts of the Muqni ' are listed in Ahlwardt's catalogue under the number 419). ${ }^{173}$ The 'Aqìla has been the subject of various commentaries (cf. GAL 1,522, II) (see fig. 26).

\subsection{Dogma of Sunnī Islam: -Zawāwī, -Ramlī}

In contrast to the work of al-Ūshī, the didactic poem on theology (tawhīd, kalām), composed by Aḥmad b. 'Abdallāh al-Jazā'irī al-Zawāwī (d. 884/1479-80 or 898/1492-3; GAL 2,326 S 2,356-7), and treating the subjects of God's unity and attributes, prophecy, saintly miracles and eschatology, was widely disseminated in West Africa (Hall 2011, 138). The poem entitled al-Jazā'iriyya fì l-tawhìd or alManzūma al-Jazā'iriyya fì l-tawhīd or - with reference to the rhyme consonant al-Lämiyya fì l-kalām consists of 357 verses in the Basīt metre (one manuscript is BSB Cod.arab. 1514).

173 Manuscripts of the 'Aqìla are Ahlwardt no. 487-94 (265, 270, 300 and 302 verses, resp.); Br. Mus., suppl., no. 87,„I; VOHD XVIIB3 no. 15 (298 verses); BSB Cod.arab. 1813. 


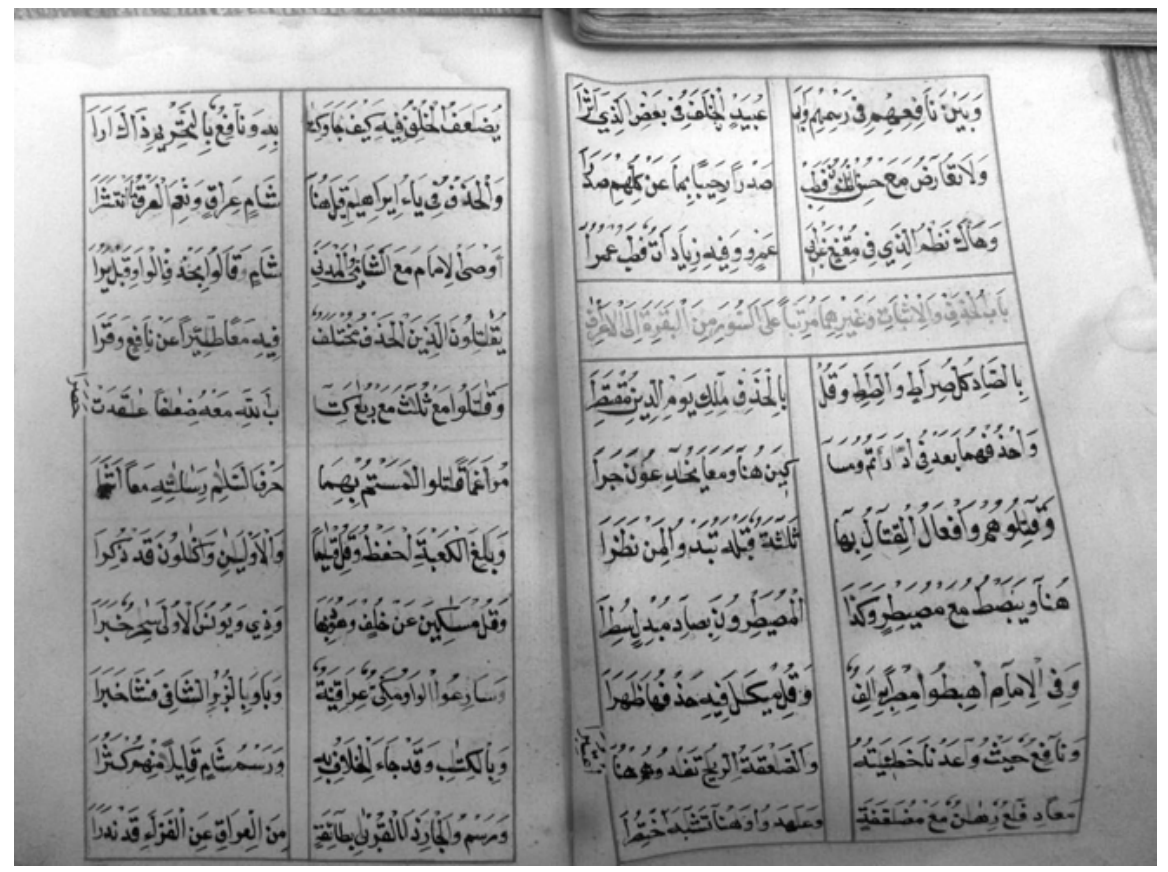

Fig. 26: Al-Shāțibī: 'Aqīlat atrāb al-qașā'id, a versification of al-Qurțubī's Muqni'; fully vocalized Naskh hand; two columns; thematic headings in red; name of the author and title of the base text in v. 3 (BSB Cod.arab. 1813, fo. 3v).

Numerous copies of the -Iqd al-farìd fi hall mushkilāt al-tawhīd or Sharh 'alā lJazā'iriyya fi 'ilm al-kalām also seem to be extant; this commentary on al-Jazā'irî's poem was written by the famous author Muhammad b. Yūsuf b. 'Umar al-Sanūsī al-Tilimsānī (d. 892/1486 or 895/1490). A manuscript of the Sharh is BSB Cod.arab. 1516 (for descriptions of two Mss. of the poem and its commentary, in possession of the BSB, see VOHD XVIIB9 nos. 180, 182).

A didactic poem of approximately 1000 Rajaz-verses entitled Nazm Șafwat alZubad fi-mà 'alayhi l-mu'tamad treating dogma from the perspective of tawhìd as well as Shāfi'î law and Sufism was written by the Syro-Palestinian author Shihāb al-Dīn Aḥmad b. al-Ḥusayn Ibn Raslān al-Ramlī al-Qudsī al-Shāfi'ī who died in Jerusalem in the month of Sha'bān in 844/1440 (GAL 2,118 S 2,113). The urjūza was composed by Ibn Raslān as a versification of the prose tract of an author called Hibatallāh b. 'Abd al-Rahịm al-Bārizī al-Ḥamawī (d. 738/1337 or 1338; GAL 2,105; Kaḥhāla 13,139) who had written his Kitāb al-Zubad about one century earlier. The poet and Shāfi ‘ j jurist Ibn Raslān did not content himself with writing an 
urjūza on al-Bārizī's text, he also compiled a commentary in explanation of it which he entitled al-Ta' lìq 'alā Șafwat al-Z. or "Notes on the Șafwat al-Zubad" (a copy of about 30 leaves is included in the multiple-text volume BSB Cod.arab. 1283; cf. VOHD XVIIB8 no. 223, part 2). Three copies of the versification Nazm Șafwat al-zubad by Ibn Raslān in the possession of the BSB Munich are the following:

1. BSB Cod.arab. 1738, a manuscript of 56 leaves in a brown partial leather volume with flap (cf. VOHD XVIIB12). In this copy the urjūza is divided into an "introduction (muqaddima) on the principles of religion", with 97 subsequent chapters $(a b w \bar{a} b)$ and a concluding section (khātima) devoted to Sufism.

2. BSB Cod.arab. 2048 (see fig. 27), a manuscript comprising two texts (cf. VOHD XVIIB12), includes, in the heading of the first (fo. 1r), a reference to the fact that the subject of the poem is Shāfi'i law: Matn al-Zubad fiqh Shāfi 'i . The copy of the Nazm in this manuscript is divided into 95 (!) chapters + 1 khätima on tașawwuf and, by my count, there are 1088 verses. The poem is written in two columns of 15 lines that are separated by rectangles in which the chapter headings have been inscribed. These have also been entered in the margins which, in addition, are filled with notes of correction. Most instances of the former type of marginalia however have been lost through trimming the paper. The text is framed with a single red line which is also used to delineate the columns.

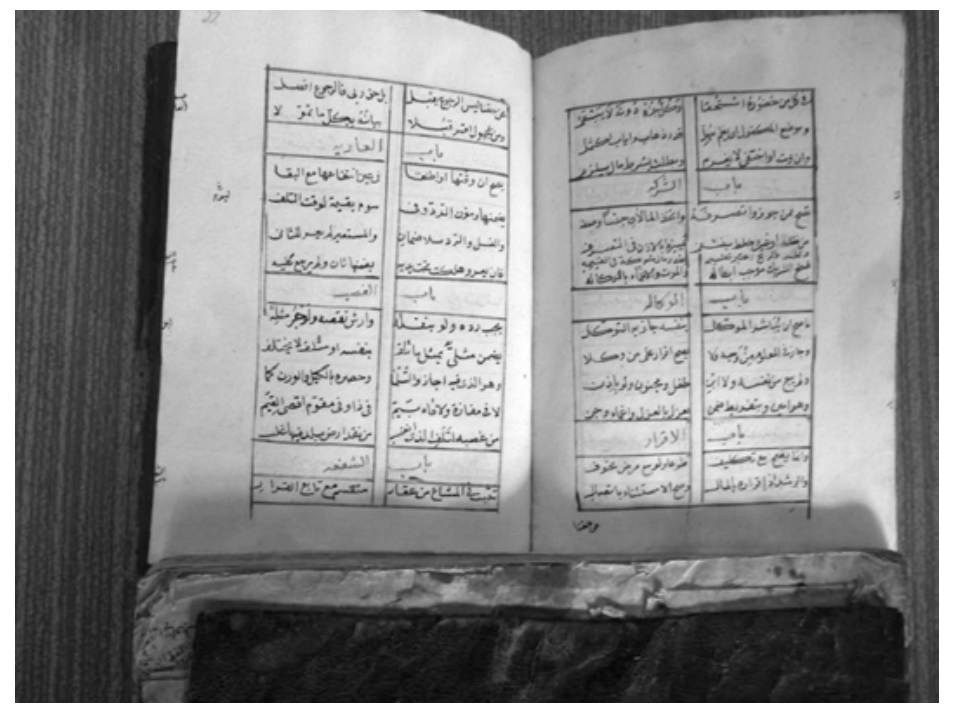

Fig. 27: Ibn Raslān: Naẓm Șafwat al-zubad, an urjūza on dogma, law and Sufism, 1200/1786; marginalia, mostly lost through paper trimming (BSB Cod.arab. 2048, fo. 21v-22r). 
The Nazm in this manuscript is followed by the copy of another didactic poem, viz. the Manzūma fì l-ma'fuwwāt of al-Aqfahsī (d. 808/1405; GAL 2,114) on pardonable sins (infra) which has been copied by the same hand in Jumādā II 1200/April 1786.

3. BSB Cod.arab. 2051 (cf. VOHD XVIIB12): a single text manuscript of 47 leaves bound in a partial red-leather volume. The marbled paper which was glued onto the covers has been cut away from the back. The poem in the colophon is dated 13. Rajab 1285/30. October 1868 and was copied by one Ahmad ibn al-Sayyid Muhammad in the "Madrasa of the tailors" of Damascus (Madrasat alkhayyātīn fì Dimashq al-Shām) who used a trained Naskhī hand with full vocalizations and diacritical points. The text, beginning with a muqaddima and ending with one khätima fì 'ilm al-tașawwuf on Islamic mysticism, extends to 1083 verses which are written in two columns on 93 pages. The poem in this manuscript includes 15 main chapters, kitāb (țahāra, șalāh, janā'iz, zakāh, șiyām, i'tikāf, hajj), bai', rahn, farā'id, nikāh, jināyāt, jihād, șayd wa-l-dhabā'ih, qaḍa) which are subdivided into secondary chapters, $b \bar{a} b$, but which are occasionally also called $n i s ̦ a \bar{b} b$. The face of the text is framed by double red lines which also separate the columns. As is the case in the parallel manuscript Cod.arab. 2048, the text of the columns is interrupted by chapter headings which however have not been inscribed in rectangles. The headings have been written with red or, sometimes, with pink colour. The latter colour has also been used to count the verses in the margins, in tens (for further details on the system of counting verses applied in this manuscript, see supra, section on page layout). Some letters used as abbreviations have been entered in the margins of the manuscript: 'ayn for 'adad = number; șād for șahīfa = page; $k \bar{a} f$ for kurrāsa = quires; $q \bar{a} f$ for $w a r a q=$ leaf. Some correction notes marked șaḥ can also be found in the margins, as well as a sign resembling the Arabic numeral seven, used as a reference both in the margins and in the text.

\subsection{Mysticism: -Bakrī, -Dīrīnī}

Didactic verses on Sufism have not only been integrated into a comprehensive poem treating dogma and law, as a khätima, i.e. seal or completion, as for instance in the above Nazm of Ibn Raslān, they have also been composed as independent texts or as versifications in their own right. A case in point is the didactic poem of 1200 verses on Sufism covering theoretical and practical aspects as well as lexicology and hagiology, authored by the prolific writer and well-known mystic Muṣțafā b. Kamāl al-Dīn al-Bakrī al-Ṣiddīqī al-Khalwatī (d. 1162/1749; GAL 
2,459 S 2,477-78; Elger, Bakrī) and it carries the title Alfìyya (cf. EAL 2,738; Mss. are BSB Cod.arab. 1362, 1443 [ = VOHD XVIIB9 no. 28, 109]). ${ }^{174}$

A shorter poem, which is a versification by the same mystical writer of an unspecified work on Sufism authored by Jalāl al-Dīn al-Suyūṭi (d. 911/1505), carries the title al-Bast al-tāmm fìnazm Risālat al-Suyūțì. It consists of only 105 verses in the Rajaz metre, whence the term urjüza can be found somewhere near the beginning of the poem (v. 11b). Addressing the traveller on the mystical path (ayyuhā al-sayyār, v. 5a), al-Bakrī claims that he composed the versification at the request of a Sufi (literally: an enamoured person, șabb, v. 9a) based on a "short but subtle text" (nubdha lațifat al-ma'ānī, v. 7b) by the "formidable" writer alSuyūṭi (al-humām al-murtaq̄i, v. 6a) concerning the mystical path. An undated copy of the - Bast or al-Basța (thus the variant title in Ms. Ahlwardt no. 3055) in a manuscript of only three folio pages is BSB Cod.arab. 1903. Both of al-Bakrì's poems include the name of the author in one of the early verses (in al-Bast, v. 4a) and, in the last verse, a statement of the place where the fair copy of the text was completed by the author (tamma bayā tively.

The initiatic chain of a Sufi, the so-called isnād al-khirqa, has also been versified, constituting a Sufi-genealogical poem. One example is the Rifā iyya-isnād in Rajaz verses, composed by the Egyptian wandering dervish and author 'Izz alDīn Abū Muhammad 'Abdal'azīz b. Aḥmad b. Sa '̄id al-Dīrīnī al-Damīrī (lived 61297/1215-97; GAL 1,588-89; -Sha'rānī, Țabaqāt 1,176; Ibn al-Mulaqqin, Ṭabaqāt 301) and incorporated in the Tabaqāt al-awliyā' 336-41 of Sirāj al-Dīn 'Umar b. alMulaqqin (d. 804/1401) ${ }^{175}$ under the title al-Urjūza al-Wajīza li-l-Dīrīnì. An abridged version of the same poem, entitled al-Qașìda al-Lāmiyya, and ascribed to the same author, was also inserted by Ibn al-Mulaqqin in Tabaqāt 334-35, 338.

In the isnād the units of the chain extend from Aḥmad al-Rifā' $1 \overline{1}$ via ['Alī] al'Ajamī al-Dhakī, a student of Abū Bakr al-Shiblī, to Abū l-Qāsim al-Junayd, Ḥasan

174 One further Urjūza on Sufism (and ethics) is entitled Sa'ādat al-dārayn fi ttibā' Sayyid alkawnayn and has been written by the Naqshbandī poet al-Ṭāhir (Zāâir) b. 'Alī al-Zaydānī alȘafadī (Kaḥhāla 5,48) who was active at the beginning of the 13th/19th c. in Istanbul. The text, dedicated to the Ottoman sultan, comprises, in BSB Cod.arab. 1761, approximately 2000 verses written in two columns (the text is interrupted by 103 chapter headings; these are also given in a table of contents on fo. $1 \mathrm{r}$ ), and it has been completed by the author during the holy night of Laylat al-mi 'rāj, i.e. 27. Rajab, of 1215/1800.

175 Cf. Sobieroj (forthcoming), "Ibn al-Mulaqqin”, in: I. B. Tauris Biographical Dictionary of Islamic Civilization. 
al-Bașrī and eventually to Muhammad. In the shortened version the isnād is adduced starting with the chronologically earlier units; in the longer version the units of the chain have been arranged in the inverse order.

\subsection{Prayer: -Sammān, -Aqfahsī}

Purely mystical prayers, i.e. untainted by magical or other self-centred preoccupations, were - exceptionally - also formulated in poetical form. Such is the case with a prayer of the type called wird composed by the Sufi Muhammad b. 'Abd alKarīm al-Sammān (d. 1189/1775; GAL S 2,535), a student of the above Muștafā alBakrī of the Khalwatiyya order. The urjūza of 34 verses has become the subject of a commentary entitled Minhat al-raḥmān 'alä Wird al-Shaykh M. al-Sammān by Muḥammad Sa'īd Ef. b. Ḥamza al-Minqār who wrote it in 1257/1841 (one manuscript of the commentary is BSB Cod.arab. 1899, see fig. 28). In his commentary he adds an excursus called khātima, based on -Ghazzālī, Fì wasā'il al-ḥājāt, in which he explains the conditions to be observed while praying. As a reason for the addition of this khātima, al-Minqār mentions that the poem was made for (literally: was tied up with) supplication and invocation (al-Urjūza ma'qūda li-l-tawassul wa-l-du' $\left.\bar{a}^{\prime}\right)$.

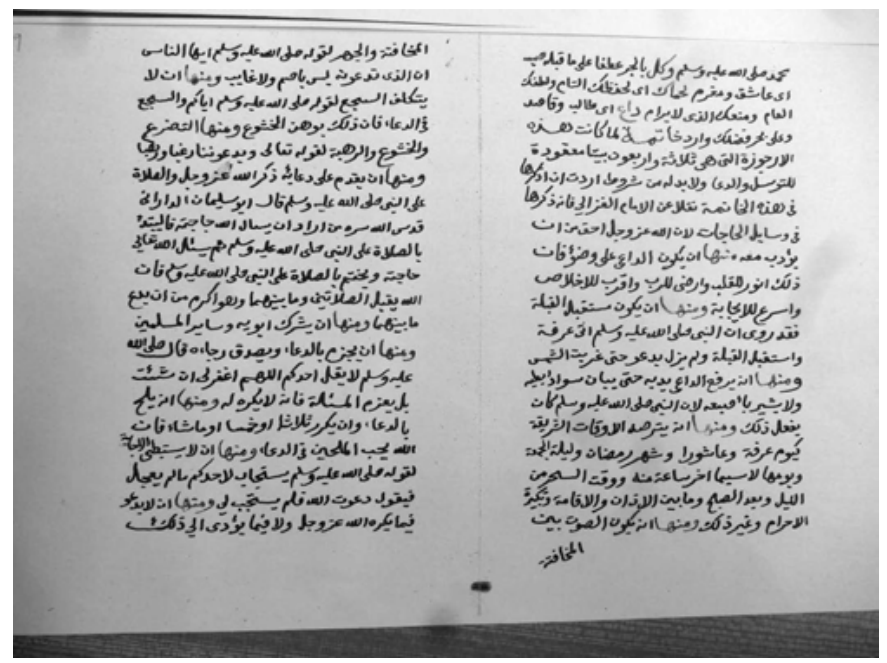

Fig. 28: Al-Minqār: Minḥat al-raḥmān, a comm. on a short urjūza on prayer, composed by alSammān, 1265/1849; excursus (khātima) on the conditions to be observed (introduced by waminhā) while praying (BSB Cod.arab. 1899, fo. 38v). 
The composition of the commentary was prompted by the discovery of certain obscure expressions contained in the urjūza which the commentator meant to elucidate by means of some clear words (aradtu an ajma' 'alayhā kalimāt jaliyya; manuscript, fo. $1 \mathrm{v}$-2r). A versified prayer with magical names is the -Qașida alJuljulūtiyya (see above).

Prayer, under the outward aspect of its ritual preconditions, is the subject of a didactic poem of Basịt-verses rhyming in the letter hā' composed by Ahmad b. 'Imād al-Dīn al-Aqfahsī al-Miṣrī al-Shāfi'ī (d. 808/1405; GAL 2,114 S 2,110). The poem deals with phenomena which belong in the legal category of pardonable impurities, and hence the poem has been called Manzūma fíl-ma'fuwwāt. A copy of the manzūma is the last of two poetical texts contained in BSB Cod.arab. 2048, with 288 verses written on 10 leaves (see fig. 29). Both poems have been written by the same delicate hand in the Naskhì style. The page layout shows the same features in both texts but in contradistinction to the first, the second poem is devoid of chapter headings. The author's name is incorporated into the third last verse of the Manzūma fì l-ma'fuwwāt (fo. 49v) where "Ibn 'Imād" asks the reader to pray to God that he forgive the author his mistakes.

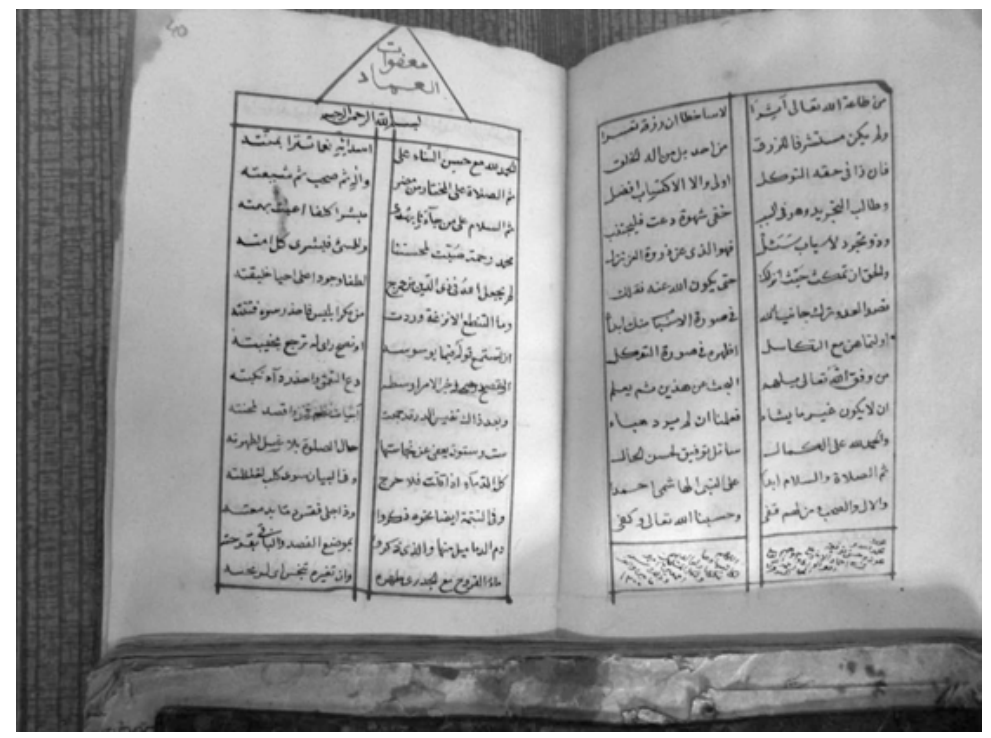

Fig. 29: Al-Aqfahsī: Manzūuma fĩ l-ma'fuwwāt, on impurities, 1200/1786; beginning of the poem and end of khätima fí l-tașawwuf of Ibn Raslān`s urjūza (BSB Cod.arab. 2048, fo. 39v-40r). 
A commentary written by Aḥmad b. 'Alī (or Aḥmad) b. Haamza al-Ramlī al-Dimashqī (d. 957/1550 or 971/1563; GAL 2,115 S 2,440) and titled Fath al-jawād bisharh Manzūmat Ibn al-'Imād is included in the carelessly executed and undated BSB Cod.arab. 1884 (the two manuscripts Zāhiriyya, Fiqh 205-206 on the other hand are dated: 1143/1730-31 and 1123/1711-12).

\subsection{Jurisprudence: Ibn al-Wardī, - Imrīțī, Ibn al-Mutaqqina, Ibn al-Hā'im, -Zaqqāq, -Rifā'ī, Ibn ‘Āshir}

Makdisi $(1981,268)$ has observed that versification was used so frequently by jurisconsults that, to distinguish it from poetry proper, it was sometimes called "lawyers' verse" (shi'r al-fuqahä').

Ibn al-Wardī, the author of the above Lāmiyya, in which he admonished his son, also wrote a poem in around 730/1329 on Shāfi' 1 ì law entitled al-Bahja alwardiyya; this is a versification of a compendium entitled al-Hāai al-ṣaghīr fì lfatāwā written by 'Abd al-Ghaffār b. 'Abd al-Karīm al-Qazwīnī (d. 665/1266). One manuscript of the Bahja, dated 1308/1891, is BSB Cod.arab. 1366 (VOHD XVIIB9 no. 32). Zakariyyā' al-Anșārī (d. 926/1520), in turn, wrote a commentary on the Bahja a manuscript of which can be found in two volumes in the BSB (Cod.arab. 1394-1395 = VOHD XVIIB9 nos. 60-61). The copying of the two volumes was completed in December 1891 and June 1892, resp. (cf. introduction to VOHD XVIIB9).

A versification of the compendium (mukhtașar) of Shāfi 'ì law entitled Taqrīb fì l-fiqh or Ghāyat al-ikhtiṣār of Abū Shujā' Aḥmad b. al-Ḥusayn al-Ișfahānī (d. after 593/1196; GAL 1,492 S 1,676) was made by the Egyptian scholar Shihāb alDīn Yahyā (b.) Nūr al-Dīn b. Mūsā al-'Imrīṭī al-Shāfi'ī al-Anșārī al-Azharī, who wrote toward the end of the ninth/fifteenth century or later (Kaḥhāla 13,234; GAL $2,418 \mathrm{~S} 2,441)$. One of the rare manuscript copies of al- Imrītī's didactic poem written in the Rajaz metre, entitled Nihāyat al-tadrīb fi nazm Ghāyat al-taqrīb, is BSB Cod.arab. 1900 (VOHD XVIIB12) which is dated 14. Dhū al-Qa'da 1306/12. July 1889 and composed of 42 folios.

In the twelfth verse of his text, on fo. $3 \mathrm{v}$ (the relatively recent manuscript displays pagination, and no foliation numbers), the author of the Urjūza mentions that, through his versification, he had tried both to treat this field of study exhaustively and to help make it easier to memorize and understand [the text of Abū Shujā']:

Nazzamtuhū mustawfiyan li-'ilmihī / musahhilan li-hifzihīi wa-fahmihī 
He also declares that while closely following the prose text in its structure, he was addressing the beginners among the students (fo. 4r, 1. 3):

Murattiban tartībahu mubayyinan / mukhātiban li-l-mubtadī mithlī anā

Towards the end of the poem, on the last page of the manuscript BSB (fo. $42 \mathrm{v}$ ), the author mentions the title of the poem along with that of the prose text (line 5), both of which share the rhyme consonant (-b):

Wa-tamma nażmu Ghāyati l-taqrībi / sammaituhū Nihāyata l-tadrībi

In the subsequent two verses the number of verses is stated (1225), and the author's name (al-Sharaf al-'Imrītīi) is added. The number of verses, exceeding one thousand, is not given in digits but expressed in fractions:

Abyātuhū alfun wa-khumsu alfin / wa-zid 'alayhā rub'u 'ushri l-alfi

In the colophon of this manuscript the date of copying is given (supra) in letters as well as in numbers and the name of the scribe is mentioned who, as indicated by his nisba, must have originated from or lived in Beirut. His full name is: Muḥammad Murād b. Maḥmūd b. Aḥmad b. Bakrī b. Aḥmad al-'Arīs/'Urays alShāfi'ī al-Bayrūtī.

On the evidence of numerous glosses in the margins (e.g. fo. 21v, 23r-v, 24r), the scribe has had access to other manuscripts of the same text from which he extracted several variant readings. The glosses commence with the words wa-fi ba'd al-nusakh, etc., or the variants quoted are followed by the expression nuskha.

In the previous year (1305/1888), the same scribe, al-Bayrūtī, also copied a commentary which al-Akhḍarī (d. 953/1546) had written on his own -Sullam almurawnaq, a didactic poem on the science of logic (infra). The manuscript displaying the name of this scribe is BSB Cod.arab. 1847, a codex of 22 folios which - like Cod.arab. 1900 - are provided with Oriental pagination (see fig. 30).

Didactic poems on a specific branch of jurisprudence, viz. the law of inheritance, have been composed, i.a. by the following authors:

1. Muhammad b. 'Alī b. al-Raḥbī Ibn al-Mutaqqina (cf. Ms. Ahlw. no. 4691);

2. Muhammad b. 'Abd al-Ṣamad al-Sakhāwī (Ms. Ahlw. no. 4709);

3. Muḥammad Sibṭ al-Māridīnī (Ms. Ahlw. no. 4716);

4. Abū l-Walīd b. al-Shiḥna (Ms. Ahlw. no. 4718);

5. Ibn al-Wardī, author of the Wașiyya li-waladihī, also wrote an urjūza on 12 questions related to the law of inheritance entitled al-Masā'il almulaqqabāt al-Wardiyya fi l-farā'iḍ (cf. GAL 2,176, ${ }_{11}$ ). 


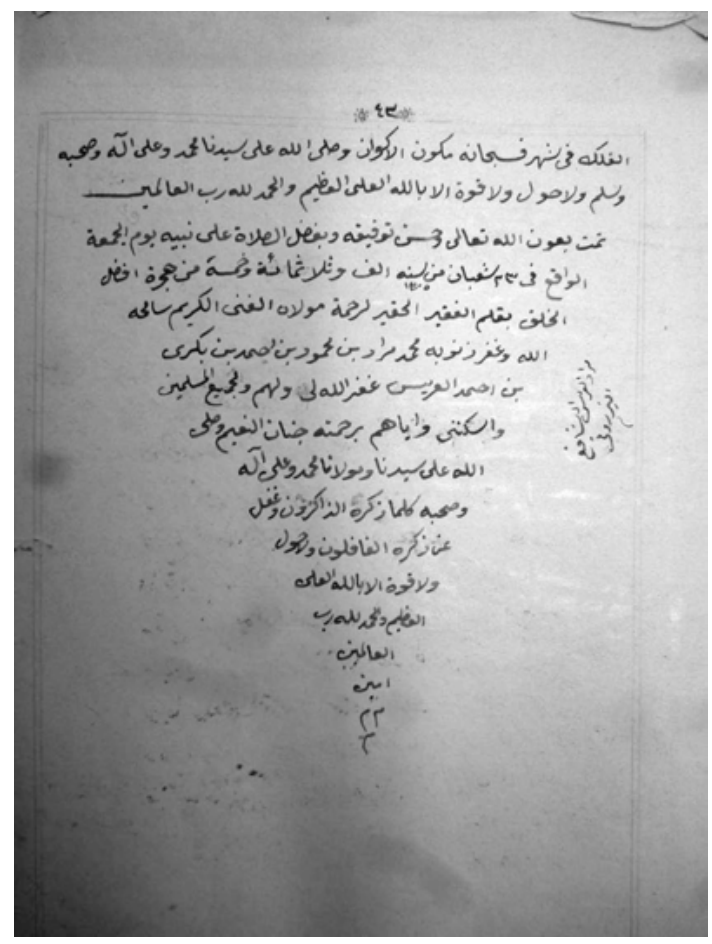

Fig. 30: Al-Akhḍarī: Sharh al-Sullam al-murawnaq, 1305/1888; colophon with name of scribe and dating (BSB Cod.arab. 1847, fo. 21v).

A copy of the -Urjūza al-Rahbiyya fì 'ilm al-farā'id on the law of inheritance by the first-mentioned Ibn al-Mutaqqina (d. 577/1181-2 or later; GAL 1,490 S 1,675) is included (fo. 239v-246r; 177 verses) in the composite manuscript BSB Cod.arab. 2054 (fig. 31) which is made up of eight texts, all dealing exclusively with fiqh (cf. VOHD XVIIB12) in general and with ['ilm al-] farā'id in particular. The manuscript is kept in a casket of partial brown leather with string and flap on which paper has been pasted, carrying an inscription of the textual contents in the following terms: majmū' fỉhi ḥ[āshiyat] al-Shinshawrī wa-ghayruhā. The high estimation in which the Urjüza has been held is proven by the fact that many commentaries and glosses, including abridgments, have been written with the intention of making it more intelligible (the above manuscript is a case in point). This valuation is also expressed in two Kāmil-verses entered anonymously on the title page of the poem in the manuscript by the scribe. The poet compares the -Rahbiyya with a hidden pearl which, if purchased for gold, would leave the seller outsmarted: 
Hādha kitābun law yubā'u bi-mithlihī

Dhahaban la-kāna l-bā'íu l-maghbūnā

A-wa-mā min al-khusrāni annaka ākhidhun

Dhahaban wa-tatruku lu'lu'an maknūnā

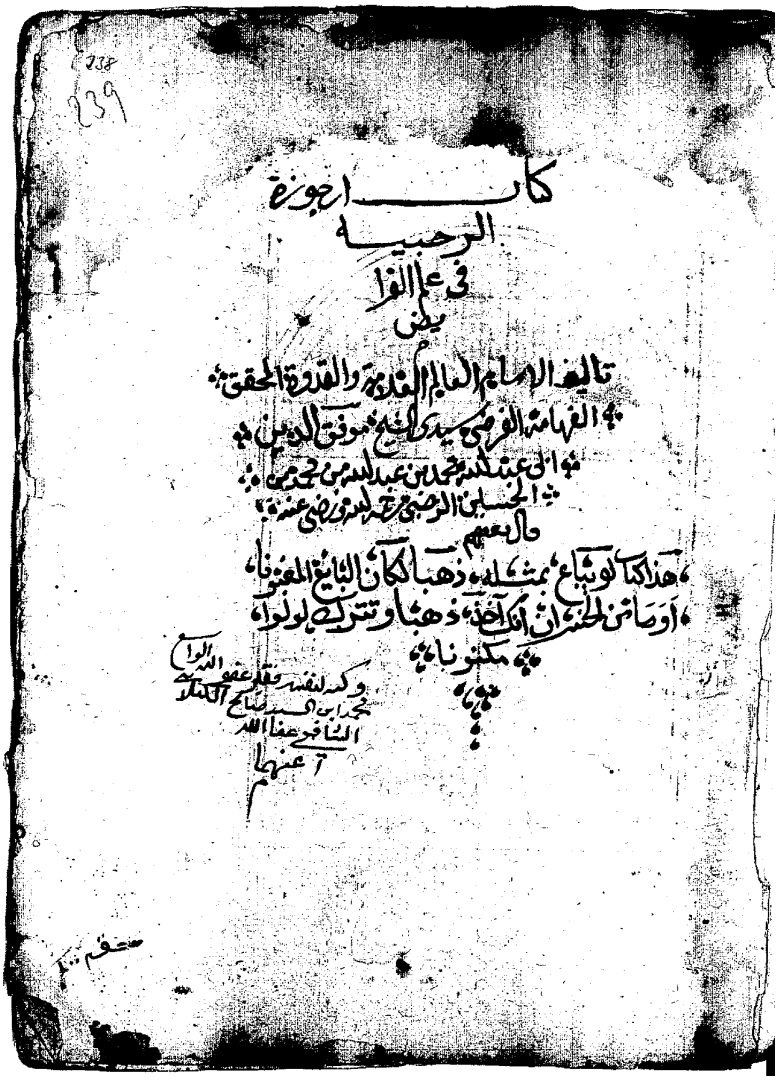

Fig. 31: Ibn al-Mutaqqina: al-Urjūza al-Raḥbiyya, on the law of inheritance, 1206/1792; title page with two verses in praise of the poem and scribal note (BSB Cod.arab. 2054, fo. 239r).

The scribe states in a note beneath the two eulogistic verses that he copied the text for his personal benefit and he mentions that he, an affiliate of the Shāfi i school of law, was called Muhammad ibn (al-Sayyid) Șāliḥ al-Kaylānī. The explicit (fo. 246r) is followed by a note entered in the inner margin according to which the same Muhammad al-Kaylānī (sic!) finished the reading under his 
teacher Muhammad al-Biqā'[ī] ${ }^{176}$ (bulighat qirā'atan 'alā shaykhinā), in Rajab 1206/February-March 1792, i.e. in the same month in which he copied the Rahbiyya (22. Rajab/17. March).

The title of the work is given in the very last verse of the poem as follows: $w a$ tammat-i l-Urjūzatu al-Rahbiyya / fì 'ilmi l-farā'iḍi l-fiqhiyya (fo. 246r). At the end of the poem Ibn al-Mutaqqina also thanks God for causing completion to come about - in one of the early verses he had asked God to help him explain this science according to the teachings of the school of Zayd al-Faradî: wa-nas'alu llāha lanā l-i'āna / fi-mā tawākhaynā mina l-ibāna (fo. 239v). Towards the end he also describes - rather vaguely - his method of explaining the legal subject, namely through symbols and allusions, i.e. poetically, and - at the same time - he summarizes it in the clearest of expressions: idh bayyannā // 'alā tarīqi l-ramzi wa-lishāra / mulakhkhișan bi-aw ḍahi l-ibāra (fo. 246r).

The text, in this manuscript, has been written in 2 columns of 15 lines on each page and is interrupted by chapter headings designed in two colours, viz., bright red and pink, resp. The latter shade of red has also been used for drawing a single line frame around the text and a double line for separating the columns. Single "drops" in red colour have been entered in the interspace between the columns functioning as verse markers, and clusters of drops fill the line beside the headings. A head-piece which, on the first page (fo. $239 \mathrm{v}$ ), incorporates the basmala, serves to decorate the text copy and to fill the verso page which only contains 8 verses. The overall aesthetic quality of the page-layout and decoration leaves much to be desired and indicates that a professional copyist, let alone an illuminator, was not engaged in this work, which the scribe had undertaken by and for himself.

There are copious glosses in the margins of the first opening (fo. 239v-240r) of this text but they become increasingly sparse on the subsequent pages. The semantic glosses entered include the quotation of the expression explained, viz. qawluhu (in red), etc. and many of the marginalia are undersigned by the names of the authorities quoted, e.g. Sibṭ [al-Māridīnī], -Shinshawrī, -Ghazzī. Other glosses include references to variant expressions in the manuscripts, e.g. wa- $f \bar{\imath}$ nuskha: wa- 'lam bi-hādhā, for: fa-'mal bi-hādhä (fo. 241r); or: wa-fi ba'ḍal-nusakh (fo. 242r, where a whole verse, with its variant readings, has been entered in the margin); some lexical explanations are given between the lines (e.g. fo. $239 \mathrm{v}$, 240r).

176 One Maḥmud b. 'Alī b. Muhammad al-Biqā'īal-Ghazzī composed a text entitled al-Minha alBiqā'iyya which is said to be an excerpt from the Raḥbiyya (cf. GAL S 1/676,Auszïge). 
Immediately following the rudimentary colophon which concludes this copy of the -Rahbiyya, the same scribe reproduced the text of another poem related to the -Urjūza of Ibn al-Mutaqqina, namely al-Tuhfa al-qudsiyya fi ikhtișār alRaḥbiyya by Ibn al-Hā'im [al-Maqdisī; d. 815/1412]; as the title indicates ("Jerusalemite gift with regard to shortening the Rahbiyya"), it is an abridgment, viz., of 79 verses (fo. 246r-249r). Ibn al-Hā'im is also known as the author of didactic poems and of other works on algebra/arithmetic (infra).

Another copy of the -Rahbiyya, with 180 verses, is included in BSB Cod.arab. 1931 which is composed of only two poetical works, the second of which is the Alfiyya on grammar by Ibn Mālik (infra). In BSB Cod.arab. 2757, by contrast, the poem of Ibn al-Mutaqqina is inserted anonymously at the end of a miscellany which comprises very diverse literary types such as poetry, Prophetic tradition, riddles, prayer, sayings as well as excerpts - mainly, but not exclusively, from works on philology. The poem only has 49 verses and is divided into ten sections all of which, except for the first, are captioned by thematic headings conventionally written in red ink.

A poem on another aspect of the science of law, viz. the duties of the judge, is the Lamiyya fi' 'ilm al-qad $\bar{a}$ ' written in the early tenth/sixteenth century by the Moroccan author 'Alī b. Qāsim b. Muhạmmad al-Tujībī al-Zaqqāq al-Fāsī (d. 912/1506; GAL 2,341-2 S 1,376) from the point of view of the Mālikì school. Commentaries, e.g. BSB Cod.arab. 1801, entitled Ta' lìq 'alā Lāmiyyat al-Zaqqāq, were composed to further the comprehension of the poem which rhymes in the letter -1 . This commentary, ${ }^{177}$ transmitted anonymously and copied in the first half of the nineteenth century somewhere in the Maghrib, presumably in Algeria, was written in a format which was intended "neither to tire through length nor to show any deficiency through briefness", but still extends to 105 folios of 19 lines per page. ${ }^{178}$

Tracts on the laws regulating marriage have also been versified. One example is BSB Cod.arab. 2055, a composite manuscript of five parts of which the second, (Nazm) Hidāyat al-fattāh li-māni' al-sifāh, treats this subject matter from the perspective of the Shāfi ì school of law. The versification, by one Aḥmad al-Rifā'î, has been discussed above in the section on page layout which may be consulted for further information.

177 For the meaning of ta 'li $q$ cf. Makdisi 1981, 114-16.

178 Another pertinent urjūza, entitled Tuhfat al-ḥukkām fi nakth al-'uqūd wa-l-aḥkām which treats Mālikī law in general and the ethics of judges in particular has been discussed in the section on the fahrasa of Ibn 'Ajība (p. 71). 
The religious obligations incumbent on the Muslim (mukallaf) who has reached intellectual "maturity" (bulūgh) formed an integral part of the science of Islamic jurisprudence. In the often very voluminous tracts on the branches (furü') of law, which were, in some cases, copied in a multiple-book-format, such subjects as purification (țahāra), fasting (șawm), pilgrimage (hajj) and almsgiving (zakāt) are discussed in individual chapters. These same subjects have also been treated in didactic poems such as the urjūza of 'Abd al-Wāhid b. Aḥmad b. 'Āshir al-Andalusī al-Fāsī (d. 1040/1630; GAL 2,613 S 2,699, Kaḥḥāla 6,205), entitled alMurshid al-mu'ìn fì l-ḍarūrī min 'ulūm al-dīn, which has been widely read and commented upon, especially in the countries of the Maghrib and West Africa (see p. 76). Since Sufism is included in the poem, well-known mystics have also composed commentaries on the Murshid, offering a distinctly mystical reinterpretation of legal issues. One such mystic was "the Sufi saint of the twentieth century" (the title of a romanticizing biography written by Martin Lings, 1971), Ahmad b. Muṣtafā b. 'Alīwa of Mustaghānam in modern Algeria (d. 1353/1934; Kaḥhāla 2,179). Two such manuscripts, with commentaries, have been found: one is BSB Cod.arab. 1702/1; another such manuscript, deficient both at the beginning and at the end, and probably authored by a different mystic, is BSB Cod.arab. 1951; the latter was written by a Maghribī hand, albeit with incomplete diacritical points.

\subsection{Logic: -Akhḍarī}

A didactic poem on logic, with 94 or 144 verses in the Rajaz metre, is al-Sullam almurawnaq (murawniq) fì l-mantiq of Abū Zayd 'Abd al-Raḥmān b. Muhammad b. 'Āmir b. al-Walī al-Akhḍarī (d. 953/1546; GAL 2,614 S 2,705). Written in 941/153435 (HKh 3,610), the poem has given rise to the composition of a number of commentaries (see fig. 32; also e.g. Zāhiriyya, falsafa 126-132) and has itself been considered a versification of the much copied Mukhtașar entitled İsāghūjì (not related to the Isagoge of Porphyry) fi 'ilm al-manțiq (cf. Ahlwardt no. 5191; VOHD XVIIB10 no. 373) by Athīr al-Dīn al-Mufaḍḍal b. 'Umar al-Abharī (d. 663/1265; GAL 1,608, 23 $\mathrm{S} 1,839)$. The Sullam seems to have enjoyed special popularity in the countries of the Maghrib and, accordingly, formed part of the curriculum of the above-mentioned highly venerated eighteenth century Moroccan Sufi Ibn 'Ajība.

Manuscripts of the -Sullam include BSB Cod.arab. 1437 ( = VOHD XVIIB9 no. 103) and Zāhiriyya, falsafa 125ff.; the manuscript in possession of the BSB contains 16 loose leaves and was copied in 1201/1787 by a scribe called Muṣțafā 'Abdallāh al-Majdhūbī originating from Asyūṭ, "for himself and those who succeed him". The manuscript is filled, in the margins and also between the lines, 
with glosses written in a circular shape around the main text, obviously motivated by aesthetic considerations. In the last marginal gloss (fo. 16r) the scribe informs the reader that he received his comments ( $t a$ ' liq) "from the mouth" of his teacher Muḥammad al-Shanawānī during the latter`s classes at Azhar university in Sha' bān 1194/1780.

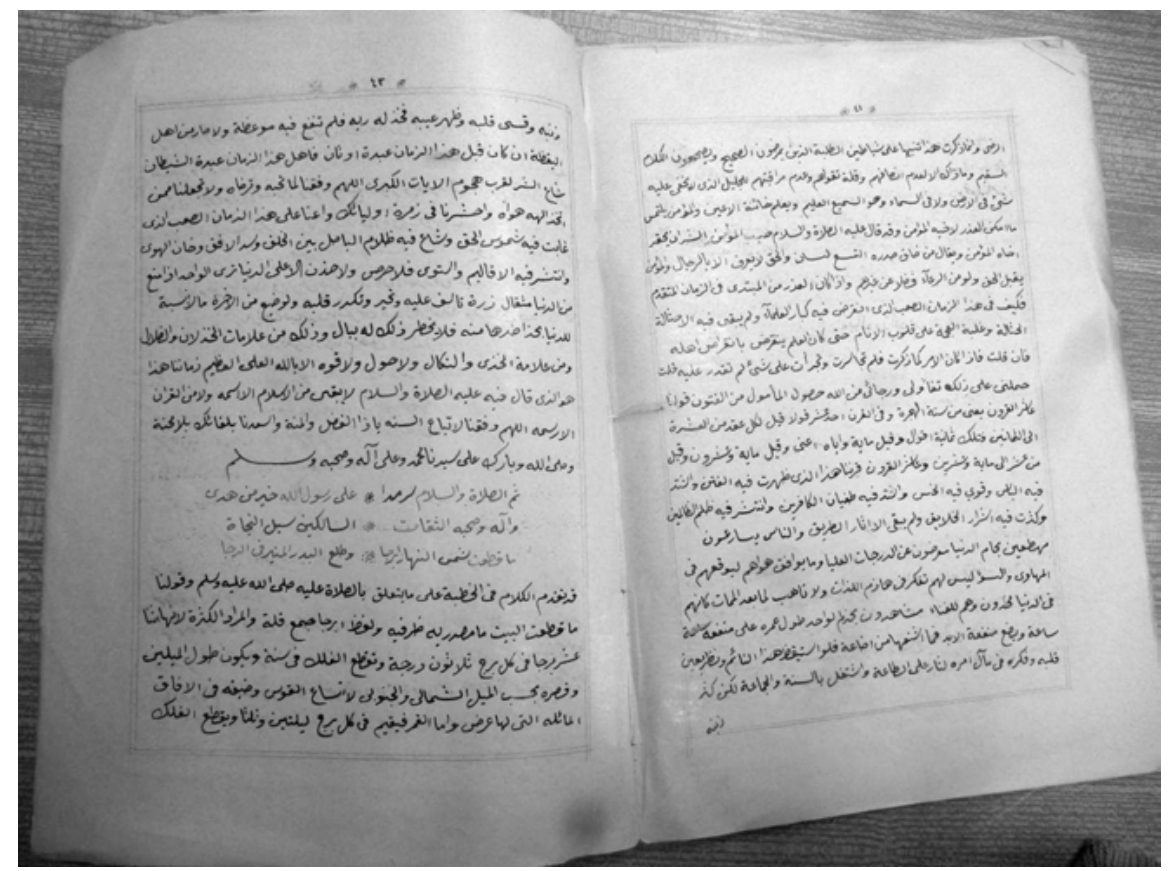

Fig. 32: Al-Akhḍarī: Sharh al-Sullam al-murawnaq, 1305/1888; end of author's own comm.; the verses of the poem quoted are written with red ink (BSB Cod.arab. 1847, fo. 20v-21r).

Two commentaries on the -Sullam are included in BSB Cod.arab. 1632 (= VOHD XVIIB9 no. 298), of which the shorter one (part two) was composed by the author, al-Akhḍarī, himself (fo. 90v-112v), while the longer one (part one, fo. 1v-86r) was recorded in the manuscript anonymously. The two texts were copied in 1119/1708, in Maknāsa (part one) and 1103/1691, respectively, by a scribe (or two scribes) who adopted a Maghribī style of writing.

In this manuscript, the author's own Sharh al-Sullam is preceded by an anonymous poem of three lines in the Wāfir metre which are designed to encourage the adolescent to study while he is still young and his mind still receptive to knowledge. He is also asked to feel content when given the honour of seeing those 
present stay silent while he alone speaks. The short poem's incipit runs: ta'allam yā fatan wa-l-'ūdu rațbun / wa-dhihnuka țayyibun wa-l-fahmu qābil. ${ }^{179}$

Glosses on the -Sullam were still being composed in the Maghrib region in the first half of the nineteenth century; such is the case with the Hāshiya 'alā sharh Muhammad al-Bannānī 'alā l-Sullam authored by 'Alī b. Idrīs al-Qașṣāra al-Ḥimyarī and completed by him in a fair copy, Ramaḍān 1249/February 1834. In BSB Cod.arab. 2012, this text has been copied by one Muhammad b. al-Mukhtār alMālikì in 1267/1851 or earlier, viz. at most 8 years after the author's death. The extensive glosses which cover 123 pages with mostly 25 lines have been incorporated in a multiple-text volume which also includes a commentary by the famous theologian 'Adud al-Dīn al-İjī (d. 756/1355; GAL 2,267-71) on the principles of (Mālikī) law by Ibn al-Ḥājib (d. 646/1249); this commentary, entitled Sharh Mukhtașar Ibn al-Hājib, is conspicuous because of the wide blank spaces on many of its pages which were obviously meant to be filled with quotations from the base-text. Both literary works, followed and concluded by a short paranetic tract (faṣl) on "patient endurance" (șabr) by Ibn Taymiyya (d. 682/1283), were written in the Maghribī style by the not easily legible hand of Muhammad b. alMukhtār who, in the colophon of the second work, confides to the reader that he copied the Mukhtașar from an old manuscript (min nuskha 'atiqa), for himself and "thereafter" for his son.

\subsection{Disputation: -Kawākibī}

An urjūza of 56 verses devoted to the art of disputation (ādāb al-bahth), which in the traditional classification of sciences was counted among the subjects of philosophy, was composed by the Syrian author Abū l-Su'ūd b. Ahmad b. Muḥammad al-Kawākibī al-Ḥalabī (d. 1137/1725; GAL 2,411,24). Al-Kawākibī also wrote a commentary in explanation of his own poem entitled Sharh Tuhfat altullāb fi nazm al-ādāb, "commentary on the Gift to students relating to the versification of the art [of disputation]". One manuscript of the commentary, which includes the Rajaz-verses, is BSB Cod.arab. 2375 (= VOHD XVIIB10 no. 410) which

179 Other didactic poems on logic have been composed, i. a., by the philosopher Ibn Sīnā, Abū 'Alī al-Ḥusayn b. 'Abdallāh (d. 428/1037; GAL 1,589-99), entitled al-Urjūza fí l-manțiq or al-Qașīda al-muzdawija (cf. Z̄āhiriyya 1970, 172), and by the mystic 'Abd al-Ghanī b. Ismā'īl al-Nābulusī (d. 1143/1731; GAL 2,454-58), Urjūzat al-Nābulusi fi l-manțiq (op. cit. 173). The Syrian Sufi has also written a commentary elucidating his own poem (Sharh Urjūzat etc.; loc. cit.). 
extends from fo. $7 \mathrm{r}$-20v within a composite manuscript of 12 parts dated between 991/1583 and 1113/1702.

\subsection{Algebra: Ibn al-Hā'im}

A didactic poem on algebra extending in the manuscript copies from 57 to 60 verses (the number 59: wa-abyātuhā tis'un wa-khamsūna ilkh., is mentioned in the penultimate verse of Ms. Zāhhiriyya, Riyā diyyāt, p. 66) by an author called Ibn al-Hā' im al-Ma'arrī al-Maqdisī who died in Jerusalem in 815/1412 (GAL 2,153-5 S 2,154) is al-Muqni' fi 'ilm al-jabr wa-l-muqäbala. A commentary of 18 folios on the -Muqni' written about hundred years after the composition of the metrical work, by Zakariyyā' al-Anșārī (d. 926/1520) and entitled Fatḥ al-mubdi bi-sharh alMuqni', is BSB Cod.arab. 1488 (= VOHD XVIIB9 no. 154). Ibn al-Hā'im also wrote a commentary on the -Urjūza al-Yāsiminiyya on al-jabr wa-l-muqābala by 'Abdallāh b. Muhạammad Ibn Yāsimīn (cf. Ẓāhiriyya, Riyāḍiyyāt, p. 56).

\subsection{Medicine: Ibn Sīnā}

The unrivalled philosopher, mystic and physician Abū 'Alī al-Ḥusayn ibn 'Abdallāh Ibn Sīnā al-Qānūnì, al-Shaykh al-Ra'īs, known in the west as Avicenna (d. 428/1037; GAL 1,589-99 S 1,812; EAL 1,373-75), composed, as part of his astonishingly rich literary oeuvre, a number of didactic poems on medicine, of which presumably the best known is Manzūma (or Urjūza or Alfiyya) fì (ușūl) al-țibb in 1316 Rajaz-verses (cf. Ahlwardt no. 6268, 6295; GAL S 1,823,81; the text has been edited by Henri Jahier, Paris 1956; the Latin title runs: Cantica Avicennae).

Two smaller didactic poems by Ibn Sīnā on some areas of medicine are extant in BSB Cod.arab. 1985, a volume of miscellaneous content, mainly consisting of poetic verses. The first (fo. 110v-103r) is entitled Urjūza fi l-Mujarrabāt min alaḥkām al-nujūmiyya wa-l-qawānīn al-țibbiyya or Urjūza fì l-Mujarrabāt (this title variant can be found in Ms. Br. Mus. no. 893, 5 and has been translated as "Poema de medicamentis experimento comprobatis" by Cureton, the cataloguer) or simply Mujarrabāt, i. e., "Tested medical procedures” (cf. GAL 1,599,89) and starts as follows: bada'tu bismillāhi fì nazmin ḥasan / adhkuru mā jarrabtuhū țūla lzamān. This poem with a length of ca. 120 verses (in other copies up to 256 verses) is said to have been composed by Ibn Sīnā 40 days before his death - inclusion of the number forty, hallowed by Islamic tradition (cf. Rāzì, Mirṣād al- 'ibād 282), may have served to enhance the credibility of the medical procedures recommended in the poetical text. The copy of this Urjūza, written in two columns of 
18-20 lines per page (face of text: $8 \times 14 \mathrm{~cm}$ ), immediately precedes the text of the second didactic poem again ascribed to Ibn Sīnā. Final verses on some pages (fo. 101r-v, 102r) have been written in the margins at a right angle to the text. On the first three pages red "drops" have been used as verse markers, even for the verses in the margin of fo. 191r. The employment of markers between the hemistichs of each line however ceases in the middle of fo. 101v - a rarity in the page layout of a poem. The style of writing is the same in both didactic poems although in the second urjūza the Naskhī grows in size towards the end. Catchwords have been entered, even at the end of the last verse written vertically in the inner margin of fo. $101 \mathrm{v} .^{180}$

The second poem is entitled Urjūzat tadbīr al-fuḥūl fì l-uṣūl or Urjūza fì l-fuṣūl al-arba' $a$ and treats dietetics and, in particular, the properties of the seasons, their benefits to, and harmful influences on, human health, fo. 103r-106r (other copies are GAL 1,599, ${ }_{88}$ S 1,827; Ahlwardt no. 6397-99; Wien (Flügel) no. 1457). The work includes the author's name in the first of its approximately 115 (in other copies: 81 or 121) Rajaz-verses (Yaqūlu rājī rabbahū 'bnu Sīnā / wa-lam yazal billāhi musta ìnā // "Ibn Sīnā who hopes for his lord says / while he continues to ask God for help"). The text in the manuscript has been structured by creating passages ( $f a s c l$ ) which are written in two columns of 17-18 lines. The copy is headed by the formula wa-lahū ay ̣an fì l-fușūl al-arba' a ("he has also composed [the following] on the four seasons") and the word lahū has been extended across the line, thus separating the Urjüza from the previous text. As in the preceding poem, some final verses have been written in the margins at a right angle to the text (ca. 8,5x14 cm). The lack of verse markers separating the hemistichs and of a text frame gives an impression of overall carelessness in the execution of the copying by the scribe.

Ibn Sīnā's last-mentioned poem has been commented in -Qawl al-anīs wa-ldurr al-nafìs 'alā Manzūmat al-Shaykh al-Ra'īs (GAL S 1,827,88) by Madyan ibn 'Abd al-Raḥmān al-Quṣūnī (d. after 1044/1634; GAL 2,478 S 1,827,91) who practiced as a physician in the Dār al-Shifā' hospital in Cairo. A copy of this Sharh is included in Ms. Wien (Flügel) no. 1457, part 1 (fo. 1v-79r), and is dated 1140/1728. The volume described by Gustav Flügel and previously (in 1215/1800) owned by al-Sayyid Mușțafā b. Mas'ūd, a physician who worked in the Ottoman Sultan's palace (min al-ațibbā' al-khāșșa), also includes, as a second part, the text of the [Urjūza fì l-]Mujarrabāt.

180 Another Ms. of the Urjūza fi l-mujarrabāt is Bodleian Library, MS. Arab. f. 49 (item 5), described in some detail in the recently published catalogue Bodleian (Savage-Smith) under "Entry 91”. 


\subsection{Grammar: -Ḥarīrī, Ibn Mālik, -'Imrīțī}

The illustrious writer al-Qāsim b. 'Alī al-Ḥarīīi (d. 516/1122; GAL 1,325-29 S 1,48689; Kahhhāla 8,108; EAL 1,272-3), author of the celebrated collection of narrations entitled Maqāmāt and written in rhymed prose, also composed a grammar in verse, viz. the Mulhat al-i'rā $b$, "Witticism on desinential inflection" (GAL 1,328, vII S1,488; Breslau [Wrocław] no. 213). A copy of this poem of 373 verses in the Rajazmetre is included in BSB Cod.arab. 2036 (fig. 33), an undated manuscript of 14 trimmed leaves (format: 12,5x17 cm, face of text: 10x14 cm) bound in a partial brownish-red leather volume without a flap.

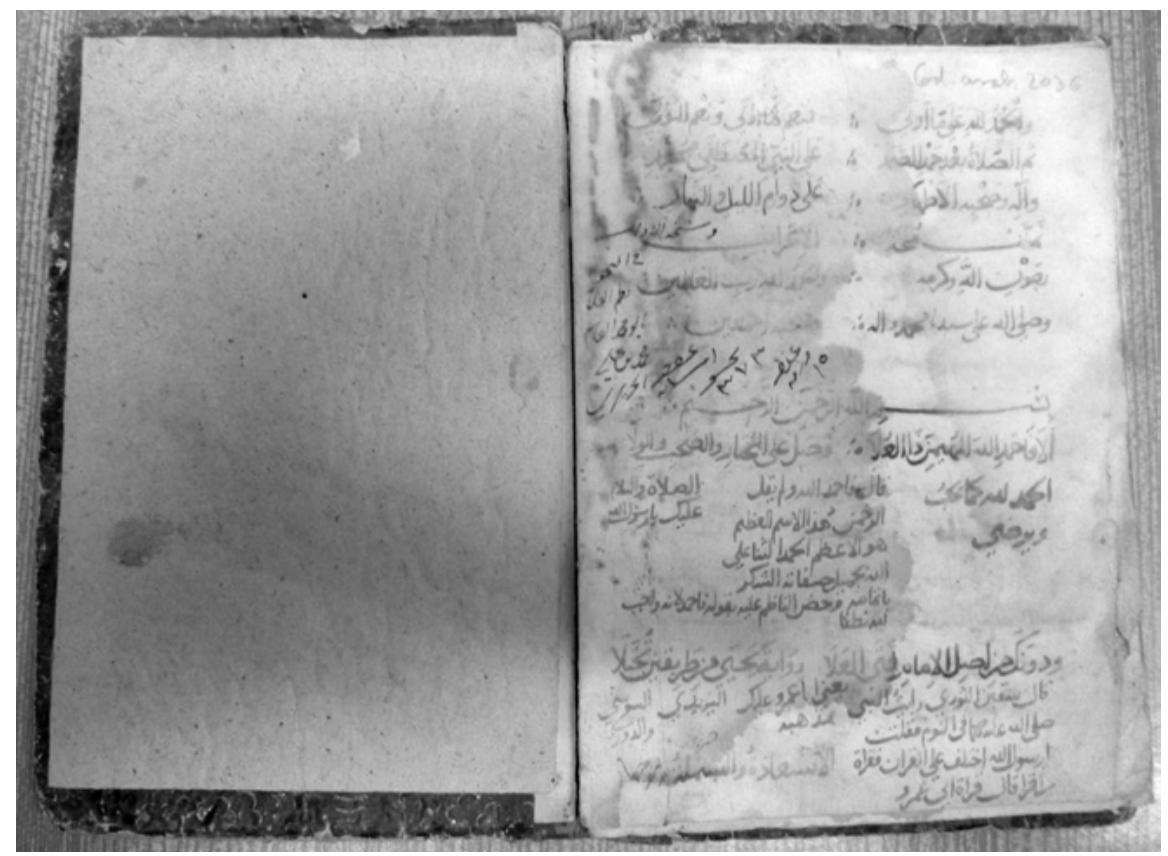

Fig. 33: Al-Ḥarīīi: Mulhat al-i'rāb, an urjūza on grammar; end of poem and first verse of Manżūma fĩ riwāyat al-Imām Yahyyā, a poem (Ṭawīl) on Koranic readings, with commentary (BSB Cod.arab. 2036, fo. 13v).

On account of the trimming of the paper, glosses in the margins have been lost. The copy seems to be very old and the black ink - a fully vocalized Naskhī hand with diacritical dots - has faded in many places, in particular in the opening of the codex. Words which became illegible as a result of this deterioration have 
been rewritten by a recent hand (fo. 1v). However, the red markings, viz. the headings and clusters of (three) drops between the hemistichs and at the end of each line seem to have remained unaffected. The same recent hand has entered a statement on the verso-side of the last leaf concerning the number of verses (373) and the number of leaves (15), statements which can also be found on the title page (fo. 1r), albeit faded. The number of verses as well as that of the leaves inscribed in the manuscript differs from that of my own count, a discrepancy which may be explained through the omission of a single leaf. ${ }^{181}$

One the last page, beneath the explicit of the grammatical urjūza, is the first verse of another poem on the readings of the Koran (qirā'a ât) according to Yahyā [= ibn al-Mubārak al-Yazīdī?]; the poem is written in the Tawīl-metre, rhymes with -lā, and there is no indication of title or author's name. However, only the first two verses of this poem are found - they are complemented by a commentary written in red - and thus it appears that the manuscript is defective at the end. A comparison with the Ms. Azhar 1,146 shows that the text is identical with a poem entitled Manzūma fì riwāyat al-Imām Yahyā, authored by a younger contemporary of al-Ḥarīrī, Aḥmad b. Wahbān b. Afụal al-zamān who died in 585/1189 (cf. Kạ̣ḥāla 2,199).

One and a half centuries after al-Harīīìs death, a more famous grammar made by Jamāl al-Dīn Muhammad b. 'Abdallāh Ibn Mālik al-Jayyānī al-Andalusī (d. 672/1274; GAL 1,359-63, S 1,521-27) was composed in 1000 verses, whence the name of the poem: Alfiyyat Ibn Mālik.

Ms. BSB Cod.arab. 1931, an undated (perhaps $19^{\text {th }}$ c.) booklet of 10 leaves with no binding, is composed of two parts, viz., the Alfiyya of Ibn Mālik and, preceding it, the didactic poem of Ibn al-Mutaqqina, the -Rahbiyya, on the law of inheritance.

Both texts are written in two columns of 25 lines to the page, in a carefully executed Naskhī hand, and they are provided, in the margins, by verse numbers given in tens in Arabic numerals. The first text, i.e. the -Rahbiyya, numbers 180 verses, the second which is defective at the end, breaks off after the $223^{\text {rd }}$ verse. As the last verso page has been left blank it cannot be assumed that pages have been lost in this manuscript. The numbers have been entered in the margins with the same red ink used to add the thematic headings that interrupt the columns in both texts. The sparsely added vocalizations (e.g. fo. $5 \mathrm{v}$ ) are also in red. The first

181 Another copy of the same urjüza is BSB Cod.arab. 2781 (dated 1284/1867) where the title of work can be seen to be included in the first hemistich (wa-qad taqaḍat Mulhatu l-i'rābi / mūda'atan badā'i'a l-i'rāai) of the last section of the poem (khātima), i.e. in the seventh to last verse of this copy of 371 verses. 
number (10) inscribed in the margin of both texts (fo.s. $1 \mathrm{v}, 5 \mathrm{v}$ ) is headed by the word 'adad, i.e. number. Both poems are introduced by the basmala formula, "in the name of God", which has been written as a heading.

A complete manuscript copy of the Alfiyya is BSB Cod.arab. 2053, encompassing 44 leaves with a format of 11x16,5 and a text face of $6 \times 11 \mathrm{cms}$. The volume is bound in brown partial leather and the flap has been lost. The text copy extending from fo. $1 v$ to $43 \mathrm{r}$ was written in the standard format, viz. in 2 columns (of 13 lines) which are framed by a single red line as are the headings which have also been written with red ink. The style of writing is a small Naskhī hand with full diacritical dots and vocalizations. Verse numbers, which end at v. 30, have been entered in the margins by a recent hand. The copy has been collated with its exemplar as is apparent from the note inscribed in the margin of fo. 43r, viz. balagh muqābalatan bi-'awnihì ta'ālā. A reader's note can be found in the outer margin of fo. 16r, as follows: qad țāla' a bi-hādhihī l-nuskha.

There are numbers of reference within the text of this copy as well as in the margins where they have been written in red above the extensive explanatory glosses; some of the reference numbers have also been underlined. Apart from the numbers, some letters, namely $t \bar{a}^{\prime}$ and $k \bar{a} f$, have also been used as signs of reference. Explanatory glosses can be found both in the margins and between the lines. However, after fo. 16r, the margins have been left blank except for a few correction notes.

The undated copy lacks a colophon and the scribe's name is unknown. However, the dogmatico-mystical text entitled Matn 'Aqìdat al-ghayb which follows the poem on grammar in this manuscript was written by one Faqī Hasan whose more recent hand is different from that which copied the Alfiyya.

Versifications were also made of the [-Muqaddima] al-Ājurrūmiyya of the Moroccan author of Berber origin, Abū 'Abdallāh Muhammad b. M. b. Dā'ūd alȘanhājī al-Fāsī b. Ājurrūm (d. 723/1323; GAL 2,308-10 S 2,332-35); this is one of the most popular textbooks of Arabic grammar ever written (cf. TDVİA 19,295-96; EAL 1,308), particularly in the Maghrib. Through translations and printed editions it also became known in Europe from the late sixteenth c. onwards. The numerous commentaries compiled in explanation of this epitome include even Sufi tracts a fact which testifies to the efforts made to interpret the phenomena of grammar in terms of Islamic mysticism. ${ }^{182}$

182 Cf. Chiabotti 2008/9, 385-402. As well as al-Qushayrī, Aḥmad Ibn 'Ajība al-Shādhilī of Fes (d. 1224/1809) also wrote a commentary in the spirit of Sufism on a grammatical textbook, namely on the -Ājurrūmiyya (a Ms. is BSB Cod.arab. 1678, fo. 1r-4v). 
One of the few versifications made of the Muqaddima is the Nazm alĀjurrūmiyya composed by Yahyā (b.) Nūr al-Dīn al-'Imrīṭi (al-'Amrītī) al-Azharī (d. 890/1484-85; GAL S 2,441-2; the text is briefly described by Ahlwardt no. 6693); he was mentioned above as the author of a didactic poem on the branches of Shāfi 'ì law, Nihāyat al-tadrīb fì nażm Ghāyat al-taqrīb. Incidentally, this specialist in versification also wrote a didactic poem against the consumption of coffee; a copy of this urjūza, entitled al-Muqaddima al-Manșūra, can be found in the Gotha library $^{183}$ (Pertsch 1878-92, no. 2107; cf. GAL S 2,442,5). One manuscript of the above versification of the -Ājurrūmiyya is BSB Cod.arab. 2039, a codex of only 10 leaves dated end of Dhū al-Qa'da 1248/ca. 21. April 1833 which includes both the text of the Nazm as well as that of another, anonymous poem on grammar. The scribe's name is given in the colophon of the Nazm (fo. 8v (fig. 34)) as Muhammad 'Alā' al-Dīn b. 'Ābidīn who, by evidence of the name inscribed in a stamp on fo. 1r, seems to be identical with one of the previous owners of the manuscript who were well-known Syrian scholars belonging to the Hanafi madh-hab (cf. TDVIA 19,292-93). The copyist's name however has been tampered with: the words following "Muhammad" have been scratched out and replaced by the name 'Alā' al-Dīn b. 'Ābidīn.

In the introduction to his poem al-'Imrītị states that he composed the versification for the beginners (li-l-mubtadì) among the students (v. 11) - the textbook of Ibn Ājurrūm was originally written for young children (cf. EAL 1,308) - and that he omitted what can be dispensed with, but added what might be useful (fawa'id); he also says that he conceived of his poem as a commentary on the grammatical tract (fa-jā'a mithla al-sharhi li-al-kitābi; v. 12). The poet ends the introduction to his urjūza with a prayer in which he expresses the wish that he who memorizes and understands the versification may, through his knowledge, be useful [to other members of the umma, community] (wa-an yakūna nāfi'an bi'ilmihī / man i'tanā li-hifzihī wa-fahmihì). In a poetical addition of 13 verses (in Ms. Ahlw. no. 6693: 8 verses) headed by the words $b \bar{a} b$ al-muḍa $f$, al-'Imrītī includes the date of composition of his text (fo. $8 \mathrm{v}, 1.8$ ) as well as his own name.

183 The "Herzogliche Bibliothek zu Gotha" in the lifetime of Wilhelm Pertsch (d. 1899) is now called: "Universitäts- und Forschungsbibliothek Erfurt/Gotha". 


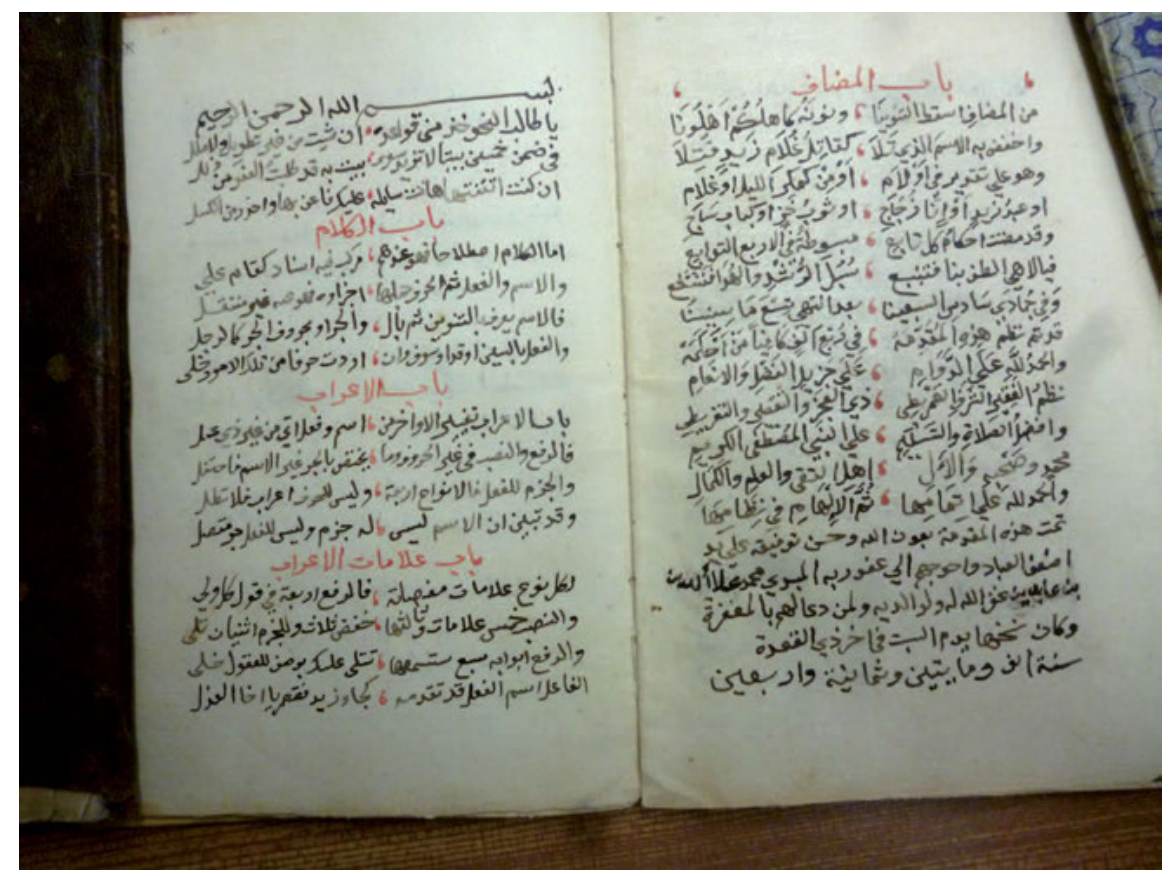

Fig. 34: Al-'Imrīțī: Naẓm al-Ajurrūmiyya, 1248/1833; end of the versification with colophon, scribe's name and dating; beginning of a further poem on grammar (BSB Cod.arab. 2039, fo. $8 v-9 r)$.

According to my count of the Ms. BSB, the Nazm al-Ājurrūmiyya encompasses 249 verses whereas Ahlwardt mentions the number 251, based on his examination of the Ms. SBB Pm. 326. The text in Ms. BSB is written in two columns of 19 lines which are interrupted by chapter headings. These, as well as the single drops employed as markers between the hemistichs in each line, have been written using red colour.

The second poem in Cod.arab. 2039 (fo. 9r-10v), copied by the same hand, on 1. Dhū al-Qa'da 1250/1. March 1835 - i.e. nearly two years after the completion of the copy of the first poem - extends to 50 verses in the Basitt-metre rhyming in the letter -lām and beginning with an address to the student of the Arabic language, viz., yā țāliba l-naḥwi khudh minnī qawā'idahū. 


\subsection{Rhetoric: -Akhḍarī, -Munayyir}

The above-mentioned 'Abd al-Raḥmān b. Muhammad al-Akhḍarī (d. 953/1546) wrote a versification entitled al-Jawhar al-maknūn fì șadaf al-thalāthat al-funūn of the Talkhịs al-Miftāh of the -Khațīb Dimashq al-Qazwīnī (d. 739/1338; GAL 2,2627 S 2,15-16) which is an elaboration of that part of Yūsuf b. Abī Bakr al-Sakkākīs (d. 626/1229; GAL 1,352-6 S 1,515-9) "Key of the sciences”, Miftāh al-'ulūm, concerning rhetoric.

Mss. of al-Akhḍarī's didactic poem are Gotha no. 2791 and Br. Mus. no. 421,20 (ca. 10 folios); the commentary by al-Damanhūrī al-Azharī (d. 1192/1778) of 51 folios entitled Hilyat al-lubb al-mașūn 'alā l-Jawhar al-maknūn on al-Akhḍarī, copied about 1280/1863-73 by various Maghribī hands, is found in BSB Cod.arab. 1929.

The Talkhīṣ al-miftāḥ of al-Qazwīnī which, in BSB Cod.arab. 2368 (= VOHD XVIIB10 no. 484), extends to approximately 50 folios, was memorized by one Ḥamza b. Ṭūrghūd (or Durghūd, d. 979/1571) on his long journey from Constantinople to Mekka; thus inspired, he claims to have composed a tract in Damascus on his return from the pilgrimage, again devoted to rhetoric, entitled al-Masālik fì l-ma'ānì wa-l-bayān (one manuscript of the Masālik is Berlin, Hs. or. 4471 [= VOHD XVIIB3 no. 465]).

The multiple-text volume BSB Cod.arab. 1133 (= VOHD XVIIB8 no. 76) contains three didactic poems composed by Muhammad Șālị̣ b. Aḥmad b. Sa'īd alMunayyir al-Dimashqī al-Shāfi'î̀ (d. 1321/1903; Kaḥhāla 10,80), the second of which focuses on tropes, i.e. rhetoric ('ilm al-bayān), and is entitled 'Iqd al-darārī al-ajmal fì ḥaqīqat wa-'alāqat al-majāz al-mursal (fo. 19r-22v); the other two poems are (1.) al-'Uqūd al-ghāliya fì uṣūl al-manțiq al-'āliya, on logic, based on alAbharī's al-Īsāghūjī (fo. 7v-18r), and (3.) Hālat al-'arūḍ, on prosody (fo. 23v-42v).

The poems in this manuscript are preceded by a qașida of the same author in praise of the Ottoman Sultan 'Abd al-Hamīd (fo. 3v-4v) and by a certificate (Șūrat shahāda wa-ijāzat al-'ulamā' li-l-mu'allif min ahl Dimashq al-fayhăa') issued to alMunayyir, when he was already employed as professor at the Omayyad mosque, by four of his teachers (fo. 5v-6r). The Syrian scholars signed the ijāza with their own hands. 


\subsection{Historiography: -Bā'ūnī}

One example of a didactic poem on historiography is the -Urjūza fi l-khulafä' $w a-$ l-salāțīn umaräa al-mu'minin or - to quote the alternative title $-K$. Tuhfat alzurafä' fi tawārīkh al-mulūk wa-l-khulafä'; this concerns the rulers of Egypt, and was composed by Muḥammad b. Aḥmad b. Nāṣir al-Bā'ūnī al-Dimashqī (d. 871/1467; GAL 2,50; HKh 2,232). The poem is included in BSB Cod.arab. 1150 ( = VOHD XVIIB8 no. 93), a manuscript of 27 folios copied by a scribe who may have been related to the Azhar mosque university and who followed the Mālikì school of law, 'Alī al-Wasīmī al-Mālikī al-Azharī. According to various notes on the title page of this codex, the Urjūza fi l-khulafä' was followed by a commentary on Ibn al-Wardī's admonitory poem (Sharh Lāmiyyat Ibn al-Wardī) which however is not (anymore) extant in this manuscript. ${ }^{184}$

184 Finally, mention may be made of the multiple text volume BSB Cod.arab. 1795 which includes a versification of 121 verses in the Rajaz metre based on a prose text on the life of Muhammad entitled Mukhtașar Siyar Rasūlallāh originally written by Aḥmad ibn Fāris alQazwīnī (d. 395/1005 or 396; GAL 1,135 S 1,197-8). The anonymous poet says in his preface that he composed his work, in 11 sections, especially for beginners to memorize, and not for experienced scholars (li-mā yahiqqu hifzuhū min al-siyar // li-al-mubtadī lā al-'ālimi al-mumārisî). The historiographical poem is the tenth of fifteen texts, mainly by Jalāl al-dīn al-Suyūṭi (d. 911/1505; EI 9,913-6), in a manuscript made in the early twelfth/eighteenth century in the Maghrib as is shown by the style of writing which is distinctive of Northwest Africa. 
